\title{
Małgorzata Praczyk Mury Ceuty i Melilli. Od wykluczenia do autoseparacji
}

\begin{abstract}
Praczyk Małgorzata, Mury Ceuty i Melilli. Od wykluczenia do autoseparacji [Ceuta and Melilla border fences. From exclusion to separation]. "Przestrzenie Teorii” 24, Poznań 2015, Adam Mickiewicz University Press, pp. 145-158. ISBN 978-83-232-2982-7. ISSN 1644-6763. DOI 10.14746/pt.2015.24.8.
\end{abstract}

The article discusses the phenomenon of border fences erected in the 1990s in Ceuta and Melilla. The fences are understood as objects which have a specific agency and whose existence raises a number of activities in the political sphere, as well as having a strong impact on the symbolic sphere. On the one hand, as a consequence of the material existence of fences, there are numerous decisions made that influence practical legal solutions concerning immigrants. Immigrants themselves are also forced to take actions and decisions they would not do without the physical presence of the fence. On the other hand, recordings and photos of people who try to cross it serve as the visual message contributing to the creation of a simplified and negative image of immigrants in Europe. Furthermore, fences constitute a material representation of a new spatial paradigm existing in the world, which consists in exclusion and strengthens the binary opposition between a "worse" and "better world".

Gdy w 1989 roku z wielkim entuzjazmem obalano mur berliński dzielący Europę, wydawało się, iż zdefiniowany przez „zimną wojnę” paradygmat świata, który wyznaczany jest przez jego wyraźny podział, rozpada się wraz z upadającymi na bruk cegłami. Nie tylko tracąca rację bytu faktyczna, polityczna granica wyznaczona przez mur berliński, ale przede wszystkim symboliczna wymowa tego wydarzenia odgrywały wtedy ogromną rolę. Istniejący wcześniej mur miał wielkie, symboliczne znaczenie, które Europejczycy doskonale rozumieli i odczuwali, i które tak dobitnie wyraził John F. Kennedy w swym słynnym przemówieniu w Berlinie Zachodnim w 1963 roku słowami „Ich bin ein Berliner" nie z tymi, którzy boleśnie odczuwali skutki wzniesienia muru, stanowiło wówczas wyraz postawy humanistycznej oraz etyczną deklarację sprzeciwu wobec takiej praktyki. JFK wtedy właśnie nawoływał: „Let them come to Berlin", mówiąc o ludziach, którzy nie rozumieją, jak ogromna jest różnica między zniewolonym światem komunistycznym, symbolizowanym właśnie przez mur, a resztą świata, który miał być wolny².

1 John F. Kennedy, Przemówienie na Rudolph Wilde Platz, Berlin, 26.06.1963, $<$ http://www.jfklibrary.org>, dostęp: 15.11.2015.

2 Tamże. 
Jak się jednak szybko okazało, choć „zimna wojna” skończyła się wraz z upadkiem muru berlińskiego, paradygmat podziału pozostał nadal bardzo aktualny. Nie trzeba było czekać długo: ponad dekadę później ataki terrorystyczne z 11 września z pełną mocą uwidoczniły nowy już model podziału globu, a różnicująca potrzeba odgrodzenia się i oddzielenia od niechcianej reszty świata znalazła swój wyraz w innym murze.

Mur wzniesiony już na początku lat 90. w Ceucie nie doczekał się spektakularnej odsłony. Powołany do życia na zupełnym krańcu europejskiej wspólnoty, nie został wtedy dostrzeżony przez jej centrum na tyle, by zdefiniować na nowo sposób, w jaki Europa postrzega samą siebie. Postawienie ogrodzenia uznać można było wówczas jedynie za zwykły akt zabezpieczający, pozbawiony symbolicznej wymowy, niewymagający utożsamienia z tymi, którzy boleśnie odczuwają jego wzniesienie. Z perspektywy czasu wyraźnie jednak widać, że jego budowa stanowiła symptom zachodzącej zmiany, która szczególnie dostrzegalna jest zarówno w kontekście narosłych z czasem wokół niego symbolicznych znaczeń, jak i w kontekście uruchamianych za jego pomocą politycznych strategii.

W centrum zaproponowanych tutaj rozważań staje zatem mur rozumiany jako obiekt, który ma specyficzną, sprawczą moc oddziaływania, często wymykającą się intencjom jego fundatorów. Pragnę podkreślić, że wybudowanie obiektu o takim charakterze niesie za sobą konsekwencje zarówno w sferze politycznych działań, jak i w sferze symbolicznej, które nie miałyby miejsca bez jego fizycznej obecności. Skutki wzniesienia omawianych tu murów odczuwalne są daleko poza pograniczem, na którym są usytuowane, okazują się bowiem pełnić szereg funkcji, które przewartościowują sposób postrzegania Europy oraz świata, który ją otacza.

\section{Ceuta i Melilla - kontekst}

Ceuta i Melilla to hiszpańskie miasta znajdujące się po drugiej stronie Cieśniny Gibraltarskiej, już na kontynencie afrykańskim. Są one niewielkimi miastami - eksklawami hiszpańskimi, które otoczone są przez terytorium Maroka oraz wody Morza Śródziemnego. Miasta te, począwszy od arabskich podbojów terenów Maghrebu w VII w. n.e., niemal nieprzerwanie znajdowały się pod kontrolą Arabów, aż do czasu przejęcia w XIV w. przez Portugalię, a potem Hiszpanię․ Oba te królestwa ścierały się zresztą niejednokrotnie o panowanie na ich terytoriach. W dobie kolonialnej, na mocy traktatu feskiego z 1912 roku kontrolę nad Marokiem przejęła Francja. Hiszpania, która także rościła sobie prawa do objęcia

3 Zob. A. Dziubiński, Historia Maroka, Wrocław 1983. 
władzy nad częścią terytorium marokańskiego, zgodziła się wtedy na francuskie panowanie w Maroku pod warunkiem przyznania jej prawa do kontrolowania rejonu Ifni, terenu obecnej Sahary Zachodniej oraz północnych terenów kraju. Hiszpania na podległym jej terytorium utworzyła wtedy protektorat. Wyjątkami były Ceuta i Melilla, które nigdy nie posiadały statusu protektoratu, w przeciwieństwie do pozostałych, podległych tu Hiszpanii obszarów. Oba miasta stanowiły więc niezmiennie nierozłączną część hiszpańskiego państwa. $Z$ tego właśnie powodu, w epoce dekolonizacji, po odzyskaniu przez Maroko niepodległości w roku 1956, Ceuta i Melilla pozostały integralną częścią Hiszpanii ${ }^{4}$. Fakt ten nie był jednak obojętny królestwu Maroka, po dziś dzień oba hiszpańskie miasta nie są bowiem uznawane przez królestwo, które rości sobie do nich prawa i uznaje je za ostatnie „muzeum kolonializmu” w Afryce ${ }^{5}$. Od 1986 roku, roku akcesu Hiszpanii do Unii Europejskiej, Ceuta i Melilla nie są już jednak tylko miastami hiszpańskimi, ale także miastami Unii. Ten ostatni fakt dodatkowo komplikuje ich historię.

Jak bowiem podkreślają badacze omawianego tu pogranicza, począwszy od 1986 roku, a w szczególności od traktatu z Maastricht, eliminującego wewnętrzne granice Europy, Ceuta i Melilla stały się niezwykle wyrazistym symbolem podziału między Europą a Afryką. Granica w Ceucie i Melilli stała się wtedy granicą między chrześcijaństwem a islamem, między biednym Południem a bogatą Północą, wysoce rozwiniętym światem a tzw. „trzecim światem”, światem cywilizowanym a światem barbarzyńskim, oswojonymi „my”, a obcymi „oni” etc. Wzniesiony na granicy hiszpańsko-marokańskiej mur uwydatnił natomiast tylko owe opozycje.

\section{Mury Ceuty i Melilli}

Mury w Ceucie i Melilli powstały w celu zatrzymania fali nielegalnych imigrantów napływających do Hiszpanii przez niewystarczająco szczelną granicę marokańsko-hiszpańską. Pierwszy mur (a właściwie metalowe ogrodzenie) wzniesiony został w 1993 roku w Ceucie. Miał on $8,4 \mathrm{~km}$ długości. Nie był on jednak początkowo wystarczająco wzmocniony i łatwo było go przekroczyć, zatem w 1995 roku rozpoczęto jego umacnianie. Mur składał się z dwóch równoległych ogrodzeń o wysokości $3 \mathrm{~m}$,

4 Dla porządku zaznaczam, że o eksklawach mowa jest wtedy, gdy opisujemy terytorium Ceuty i Melilli z perspektywy Hiszpanii, z perspektywy Maroka - miasta te są bowiem enklawami i jako takie występują zazwyczaj w literaturze marokańskiej.

5 S. Saddiki, Ceuta and Melilla Fences: a EU Multidimensional Border?, Montreal 2010, s. 7, <http://www.cpsa-acsp.ca/papers-2010/Saddiki.pdf>, dostęp: 15.11.2015. 
na których szczycie umieszczono drut kolczasty (ang. razor wire) wyposażony w specjalne ostrza. Taki sam mur, tym razem o długości $10,5 \mathrm{~km}$, wzniesiono w Melilli w 1996 roku$^{6}$. Dalsze umocnienie murów nastąpiło w 2005 roku, po masowych próbach ich przekraczania przez imigrantów. Mury podniesiono z 3 do $6 \mathrm{~m}$, włączono w system kontroli śródziemnomorskiego wybrzeża (SIVE - System of Integrated Exteranal Survellance) i wyposażono w sieci kamer termicznych oraz kamer na podczerwień, czujniki ruchu i dźwięku, system radarów, wieże strażnicze ${ }^{7}$. Mur uzbrojono także w rozpylacze gazu łzawiącego ${ }^{8}$. Ponadto, w Melilli dodano kolejny element: tzw. trzeci mur, składający się z trójwymiarowej konstrukcji stalowych drutów rozciągający się na długości 2,5 metra9. Następnie, w 2007 roku zdemontowano wyżej wspomniany drut kolczasty z powodu zbyt wielu głębokich obrażeń występujących wśród nielegalnych imigrantów, jednak po fali kolejnych masowych prób jego przekroczenia w 2013 roku, przywrócono go.

\section{W stronę sprawczości muru}

W Społeczeństwie $w$ stanie oblężenia Zygmunt Bauman napisał:

Era przestrzeni rozpoczęła się wraz z powstaniem muru Hadriana i Chińskiego Muru - konstrukcji okalających starożytne imperia. Kontynuowały ją fosy, mosty zwodzone i wieże średniowiecznych miasta, a wieńczyły linie Maginota i Zygfryda wytyczone przez nowoczesne państwa, zakończyły zaś wał atlantycki i mur berliński, wzniesione przez ponadnarodowe militarne bloki ${ }^{10}$.

Jednak niespełna cztery lata po upadku muru berlińskiego w Ceucie wzniesiono inny mur, a era murów i ograniczeń wynikających z ich powstania bynajmniej nie traci na aktualności. Pisząc o swoistym końcu granic, Bauman zwraca uwagę na to, iż współcześnie świat jest już na tyle wypełniony i zglobalizowany, że ostra, dzieląca i wyłączająca granica de facto nie istnieje. Kondycja pogranicza charakteryzuje bowiem całą,

${ }^{6}$ J.C. Pinos, Building Fortress Europe? Schengen and the Case of Ceuta and Melilla, Center for International Border Reseach, Belfast 2009, s. 18-22, <http://www.qub.ac.uk/ research-centres/CentreforInternationalBordersResearch/Publications/WorkingPapers/CI BRWorkingPapers/Filetoupload,174398,en.pdf>, dostęp: 15.11.2015.

7 C.E. Mutlu, Ch.C. Leite, Dark Side of the Rock: Borders, Exceptionalism, and the Precarious Case of Ceuta and Melilla, „Eurasia Border Review” 2012, nr 3, s. 32-33.

8 X. Ribas The Border Fences of Ceuta and Melilla. A landscape for the Future?, $<$ http://www.xavierribas.com/Contents/Ceuta/Ceuta.html>, dostęp: 15.11.2015.

9 J.C. Pinos, dz. cyt., s. 19.

10 Z. Bauman, Społeczeństwo w stanie oblężenia, Warszawa 2006, s. 104-105. 
globalną przestrzeń świata. Fakt ten z pełną mocą wydobyć miały ataki terrorystyczne z 11 września ${ }^{11}$. Owa przenikalność granicy, charakterystyczna dla czasów współczesnych, świadczy niewątpliwie o ważnej zmianie, jaka zaszła w ponowoczesnym świecie, w którym przestrzeń radykalnie się skurczyła, a przepływ ludzi, usług i towarów znalazł się poniekąd ponad tradycyjnie wytyczonymi granicami. Nie o nieprzepuszczalność granicy jednak chodzi, ale raczej o to, jakie funkcje obecnie może ona pełnić. Dlaczego zatem ciągle stawiane są mury?12.

Istnienie muru prowokuje występowanie szeregu zjawisk, tak w sferze politycznej, jak i w sferze idei, które nie wystąpiłyby, gdyby mur taki nie powstał. Mówiąc inaczej, powstanie fizycznego, materialnego obiektu, jakim jest mur, istotnie wpływa na symboliczną oraz polityczną rzeczywistość. Pisząc o sprawczości muru, nie zamierzam rzecz jasna dokonywać zabiegu jego antropomorfizacji i nie chcę przez to powiedzieć, iż mur działa intencjonalnie i nabywa specyficznych, niemal magicznych własności (tzn. że np. widzi coś czy robi coś, bo tego chce). Twierdzę natomiast, że ludzie, poprzez fakt powołania takiego obiektu do życia, powodują uruchomienie procesów, które nie zawsze możliwe są do przewidzenia i które zaczynają występować właśnie dzięki jego fizycznemu zaistnieniu. Sprawczość muru przejawia się zatem dzięki jego materialności w wielowymiarowych działaniach ludzi, które uruchomione są w wyniku jego wybudowania oraz zgodnie $\mathrm{z}$ koncepcją aktora-sieci Bruno Latoura (Actor-network Theory) - dzięki relacjom, które powstają między nim a ludźmi ${ }^{13}$. Taka właściwość muru często nie jest doceniana, a to właśnie ona, jak postaram się wykazać poniżej, wydaje mi się w daleko idący sposób oddziaływać na rzeczywistość.

Zjawisko nielegalnej imigracji do Europy upowszechniło się znacznie w drugiej połowie XX wieku. Wśród najważniejszych przyczyn takiego przepływu ludności wskazuje się problemy ekonomiczne krajów, z których pochodzą imigranci w kontraście z bogactwem „świata zachodniego”, a także rozbudowane sieci powiązań między Europą a państwami tzw. „trzeciego świata”, wyrosłe na gruzach kolonializmu, czy wreszcie zmianę paradygmatu, w którym funkcjonuje współczesny świat, charakteryzującą się jego zglobalizowaniem. Przedostając się do Europy, imigranci wy-

11 Tamże, s. 104-112.

12 Przykładów na takie współcześnie powstające mury jest zresztą oczywiście więcej. Pozwolę sobie wskazać choćby na kilka znanych przykładów: mur izraelsko-palestyński, mur na granicy amerykańsko-meksykańskiej, czy mury odgradzające Romów, które powstają na Słowacji oraz ostatnio mur powstały na granicy węgiersko-serbskiej.

13 B. Latour, Splatajac na nowo to, co społeczne. Wprowadzenie do teorii aktora-sieci, Kraków 2010. 
bierają różnorakie ścieżki migracyjne, które zmieniają swe trajektorie pod wpływem działań poszczególnych państw znajdujących się na ich trasach i walczących z tym zjawiskiem. Płynność ścieżek tego ruchu nie powoduje jednak jego zmniejszenia ${ }^{14}$. Sprowadzając problem do prezentowanego tu zagadnienia, należy zatem stwierdzić, iż budowa muru nie powoduje wcale ograniczenia liczby nielegalnych imigrantów na terenie Europy (nawet jeśli w miejscu wzniesienia muru ich przepływ maleje). Powoduje natomiast, że decydują się oni na podjęcie innej drogi w kierunku Europy bądź że podejmują desperackie próby przekroczenia muru, co $\mathrm{w}$ obu przypadkach obarczone jest zwiększonym ryzykiem utraty zdrowia lub życia. Dowodzą tego dobrze statystyki, które pokazują systematyczny wzrost liczby przybywających do Europy imigrantów, szczególnie intensywny w związku z konfliktami wojennymi toczącymi się na Bliskim Wschodzie. Bieżące nasilenie fali migracji spowodowane jest natomiast pojawieniem się na międzynarodowej scenie fundamentalistycznych terrorystów działających w ramach państwa ISIS ${ }^{15}$.

Najbardziej namacalnym skutkiem wybudowania muru jest oczywiście fizyczne wymuszenie w ten sposób konkretnych zachowań. Nielegalni imigranci, chcąc przedostać się do Europy, muszą pokonać fizyczną barierę, która pojawia się na ich drodze. Podejmują zatem wiele posunięć (począwszy od budowy prowizorycznych drabin, aż po wykorzystanie specjalnego ubioru chroniącego przed drutem kolczastym), których nie podjęliby w innym wypadku. Wymuszone na imigrantach działanie nie powoduje jednak tylko ich dyskomfortu, ale także przynosi istotne skutki w sferze symbolicznej. Nagrywane na kamery zdjęcia ludzi, którzy pod osłoną nocy przekraczają mur, sprawiają bowiem, że widzimy ich, występujących od razu w roli mocno zdefiniowanej w sferze kulturowej. Ktoś, kto pokonuje w taki sposób zamknięte przed nim ogrodzenie, nie jest nikim innym, jak rabusiem dokonującym włamania, osobą wrogą, chcącą coś ukraść, potencjalnie niebezpieczną dla nas. Nie widzimy konkretnych ludzi, za którymi kryją się często tragiczne historie i którzy chcą się przedostać na teren europejskiego kontynentu po to, by uciec przed wojną i umożliwić sobie normalne życie i/lub by tu pracować. Widzimy natomiast ludzi z wrogimi zamiarami - ponieważ taki ich odbiór dyktuje nam wizualny komunikat płynący ze zdjęć i nagrań scen przekraczania muru. Owa wykluczająca funkcja muru pozwala na zasadzie opozycji zdefiniować tożsamość tych, którzy znajdują się wewnątrz („dobrych” i wymagających obrony) z jednej strony oraz tych, którzy znajdują się na zewnątrz („niebezpiecznych”, przed którymi należy się bronić) z drugiej strony.

$14<\mathrm{http} / / / \mathrm{www}$. iom.int/cms/en/sites/iom/home.html>, dostęp: 15.11.2015.

$15<$ www.iom.int>; <www.frontex.europa.eu>, dostęp: 15.11.2015. 
W 2005 roku w Melilli doszło do masowego szturmu imigrantów na ogrodzenie. Przez mur próbowało się wtedy przedostać około ośmiuset do tysiąca osób ${ }^{16}$. Sceny te pokazywane były przez europejskie media ${ }^{17}$. Podobne sceny fotografowano później niejednokrotnie, utrwalając negatywny wizerunek imigrantów. Przykładowo na nagraniach z 2013 roku widzimy anonimowe masy ludzi, często z twarzami ukrytymi w kapturach, przeskakujące przez ogrodzenie i niszczące je. Widzimy też filmy nagrane z helikopterów, które oświetlają imigrantów krążącym światłem reflektorów, co natychmiast kojarzy się z obławą na przestępców ${ }^{18}$.

Przytoczony tu obraz imigrantów umożliwia z jednej strony podjęcie konkretnych działań w sferze materialnej i politycznej, z drugiej strony, w sferze symbolicznej, wzmacnia ich obraz, właśnie jako napierających, niebezpiecznych i zagrażających Europie. W mediach, w szczególności hiszpańskich, wydarzenie to nazwane zostało „masową napaścią” na Melillę ${ }^{19}$. Obie te płaszczyzny oddziaływania owego obrazu wzmacniały i legitymizowały się wzajemnie. Negatywny obraz imigranta, który wobec opinii publicznej uruchomiony został dzięki takiemu nagraniu, przygotował między innymi grunt pod zaostrzenie wobec imigrantów działań w sferze politycznej. Natomiast konkretne, restrykcyjne działania polityczne, podejmowane wszak w opinii publicznej już nie bez powodu, skutkować mogły dalszym spotęgowaniem i wzmocnieniem niechęci wobec „obcych napaści”.

I tak, po tłumnych próbach przekroczenia muru w październiku 2005 roku, podjęto decyzję o wzmocnieniu ogrodzenia (dodanie między innymi tzw. trzeciego muru). Ponadto, na szturmowaną granicę wysłano wojsko, które przez dwa miesiące dodatkowo strzegło tego terytorium ${ }^{20}$. Jednocześnie po stronie marokańskiej podjęto kroki zmierzające do zacieśnienia kontroli nad imigrantami i wzmocnienia granicy między innymi poprzez budowę okopów. Unia Europejska przekazała też Maroko donację w wysokości 40 mln euro na rzecz walki z nielegalnymi imigrantami21. W 2005 roku poczyniono także kroki mające na celu wzmocnienie istniejącego już ogrodzenia.

16 Wydarzenia te stały się kanwą filmu pt. „Victimes de nos richesses” w reżyserii Kal Touré z 2006 roku.

${ }^{17} \mathrm{H}$. Welzer, Wojny klimatyczne: za co będziemy zabijać w XXI wieku?, Warszawa 2010, s. 152, J.M. Ortuño, Migration, Asylum and Security: The Case of Ceuta and Melilla, s. 1, Malta 2005, <http://www.libertysecurity.org/IMG/pdf/CHALLENGE-The_Case_of_ Ceuta_and_Melilla.pdf>, dostęp: 15.11.2015.

18 Film prezentujący omówioną przez mnie scenę można obejrzeć na: <https://www. youtube.com/watch?v=OFZ6k9r2gt8>, dostęp: 15.11.2015.

${ }^{19}$ C.E. Mutlu, Ch.C. Leite, dz. cyt., s. 34.

20 J.C. Pinos, dz. cyt., s. 18.

21 Tamże, s. 20. 
Oprócz opisanych powyżej działań należy również podkreślić, iż wydarzenia 2005 roku miały bardzo konkretne przełożenie na życie nielegalnych imigrantów. Sama próba przekroczenia muru zakończyła się śmiercią kilkunastu osób, jednak militaryzacja granicy oraz udzielone przez Unię Europejską wsparcie Maroka oznaczało także radykalne wzmożenie walki z imigrantami. Od tego momentu między innymi Amnesty International zaczęła informować o tzw. „nieludzkich deportacjach”22, polegających na przechwytywaniu przez marokańskie służby imigrantów i wywożeniu ich na pustynię w rejonie granicy z Algierią. Dla wielu tak deportowanych, pozostawionych często bez wody i jedzenia, kończyło się to śmiercią. Donoszono także wielokrotnie o aktach przemocy dokonywanych na imigrantach przez straże graniczne po obu stronach muru. Ostatnie takie wydarzenie na większą skalę miało miejsce w lutym 2014 roku, kiedy to na skutek ostrzału imigrantów przez strażników gumowymi kulami zginęło 15 osób, które próbowały opłynąć ogrodzenie wchodzące do wody. Fala migracji z 2015 roku, nasilona z powodu działań wojennych w Syrii, nie wpłynęła zasadniczo na zmianę w liczbie ludności przekraczającej granicę w Ceucie i Melilli.

Militaryzacja granic oraz zachowania przemocowe wzmożone po 2005 roku świadczą o tym, iż na styku hiszpańsko-marokańskim w Ceucie i Melilli nastąpiło szczególne zawieszenie praw. Mur wytworzył wokół siebie specyficzną strefę liminalną, w której wstrzymane są normy obowiązujące w „cywilizowanym świecie europejskim”. Są to normy, których zgodnie z przesłaniem uzasadniającym istnienie muru, strzec ma paradoksalnie właśnie on sam. Jednak w tym wyjątkowym świecie może się wydarzyć niemal wszystko. Jak podkreślają Can E. Mutlu i Chrisopher C. Leite, funkcją granic jest ich przejściowość, szczególna normatywna pustka, w której suwerenna władza przekazuje swoje podmioty władzy innemu suwerenowi ${ }^{23}$. Przestrzeń granicy hiszpańsko-marokańskiej dodatkowo uwydatnia ów problem, jako że podmioty władzy, czyli imigranci, przekraczają granicę państw, która jest równocześnie granicą cywilizacyjną, granicą obowiązywania różnych norm. Przestrzeń zawieszenia, przestrzeń muru, staje się ostatnim miejscem, w którym nowy, europejski suweren już przejmuje władzę nad ludźmi, ale jeszcze nie włącza ich w obieg praw obowiązujących po europejskiej stronie ogrodzenia, sytuując ich między legalnością a nielegalnością. Realna przestrzeń granicy wystawia ich zatem na doświadczenie liminalne. Podopieczni wielkiego suwerena, ci, jak ich nazywają za Judith Butler, Mutlu i Leite, „mali su-

22 C.E. Mutlu, Ch.C. Leite, dz. cyt., s. 34 .

23 Tamże, s. 25. 
wereni” („petty-sovereigns”)24, tacy jak strażnicy graniczni, urzędnicy pracujący na miejscu, służby policyjne oddelegowane do ochrony muru, często korzystają w konsekwencji z prawa do bycia poza prawem. Przedmiotem ich działań są natomiast ludzie, którzy stają się ucieleśnieniem Agambenowskiego „nagiego życia”25.

Opisane przez Giorgio Agambena zoe - nagie, biologiczne życie samo w sobie, stające w opozycji wobec bios - politycznego życia urzeczywistniającego się $\mathrm{w}$ ramach prawnego porządku państw narodowych, staje się tu przedmiotem europejskiej biopolityki ${ }^{26}$. Owa zoe - kondycja migrujących ludzi - zaczyna ujawniać się w styczności z przestrzenią muru. To przed wkroczeniem w jego obszar migranci, świadomie paląc swoje dokumenty po to, by nie wydalono ich natychmiastowo z terytorium Europy, gdy już się do niej przedostaną, stają się ludźmi odartymi z upodmiotawiającej ich bio-tożsamości. A jak zauważa Agamben, pisząc o uchodźcach: „w systemie państwa narodowego tak zwane święte i niezbywalne prawa człowieka okazują się być zupełnie pozbawione ochrony w momencie, gdy niemożliwe staje się określenie ich jako praw obywatela danego państwa"27.

Warte zaznaczenia wydaje się także to, że nie sama granica, rozumiana jako standardowe przejście graniczne, które zazwyczaj dzieli od siebie dwa państwa, ale właśnie granica - mur, która występuje w przypadku Ceuty i Melilli, powoduje szczególne zawieszenie praw, z jakim mamy tutaj do czynienia. Mur, rozciągający się na obszarze kilku kilometrów w przypadku Ceuty i kilkunastu kilometrów w przypadku Melilli, umożliwia zaistnienie szeregu zjawisk, które nie występują na zwyczajnym przejściu granicznym. Stający na straży europejskiego porządku cywilizacyjnego strażnicy walczący z „hordami barbarzyńców” sami zamieniają się czasem de facto $\mathrm{w}$ barbarzyńców, stosując metody dalece odbiegające od standardów dotyczących praw człowieka, których chce bronić Unia Europejska. Zabieg swoistego odwrócenia ról, który tu występuje, możliwy jest jednak właśnie dzięki odarciu człowieka z jego politycznego życia i istnieniu fizycznej zapory. Wybudowanie muru idzie bowiem $\mathrm{w}$ parze $\mathrm{z}$ czytelnym określeniem tych, którzy są na zewnątrz, i tych, którzy są wewnątrz. Postawienie muru stanowi symboliczną barierę przed inwazją. Role są zdefiniowane: ci, którzy napierają, to uprzedmiotowieni wrogowie i barbarzyńcy, a ci, którzy bronią muru, to bohate-

${ }_{24}$ Tamże, s. 22.

25 Tamże, s. 36.

${ }^{26}$ G. Agamben, $M y$, uchodźcy, przekł. K. Gawlicz, <http://www.egs.edu/faculty/giorgio -agamben/articles/my-uchodzcy>, dostęp: 15.11.2015.

27 Tamże. 
rowie chroniący „nas” przed natarciem z ,ich” strony. Mur dostarcza jasnych klisz (np. w postaci zdjęć czy filmów), utrwalających zdefiniowane wizerunki tak jednych, jak i drugich, a to, że w rzeczywistości ci napierający w retoryce obowiązujących w Europie praw człowieka są raczej ofiarami niż oprawcami (choćby w przypadku tych, którzy uciekają przed wojną), nie ma tu znaczenia - na rzecz walki z nielegalnymi imigrantami podejmowane są działania zarówno w sferze konkretnych politycznych decyzji, jak i w sferze symbolicznej.

Zachodząca tu sprzeczność nie jest jednak bynajmniej łatwa do przełknięcia dla Europejczyków. Mury Ceuty i Melilli nie funkcjonują bowiem jako mury dumy i chluby. Są raczej obiektami, które powodują wstyd. Różnorakie (w tym europejskie) organizacje pozarządowe starają się zwrócić uwagę na owe wstydliwe i haniebne miejsce, które sprzyja nazywaniu Europy fortecą. Oficjalna europejska polityka wizerunkowa nie zmierza do rozpropagowywania informacji na temat owej granicznej przestrzeni. Mechanizm, który sytuuje migrujących ludzi poza prawem, możliwy jest dzięki porządkowi politycznoprawnemu narzuconemu przez suwerena i w jego ramach działa, ale jego wydźwięk obnaża w rzeczywistości wstydliwą niemoc suwerena. Suwerena, który w imię obrony „cywilizowanej Europy” i jej „wyższych wartości” wyrażanych przez prawa człowiek, musi uciekać się do przemocy ${ }^{28}$. Budowa muru na granicy serbsko-węgierskiej w odpowiedzi na szczególny kryzys migracyjny w Europie, z którym mierzyła się ona na przestrzeni 2015 roku, była krytykowana przez europejskim mocodawców. Decyzja węgierskiego prezydenta Viktora Orbána odczytywana była jako przejaw rozbijania europejskiej wspólnoty. Interpretowana była także jako odżegnanie się od wymagającej jedności, europejskiej polityki otwartości wobec imigrantów, będących ofiarami konfliktu toczonego na terenie Syrii. Owa krytyka wzniesienia nowego muru nie przeszkadzała jednak $\mathrm{w}$ przyzwoleniu na istnienie podobnego ogrodzenia na granicy hiszpańskich eksklaw.

Dlaczego Europie potrzebny jest zatem mur? Bynajmniej nie dlatego, by zminimalizować liczbę imigrantów, jako że wiadomo, iż samo jego fizyczne istnienie nie powoduje zmniejszenia ogólnej liczby osób napływających z zewnątrz do Europy ${ }^{29}$. Z przeanalizowanych przykładów wynika, iż odgrywa on istotną rolę $\mathrm{w}$ przeprowadzaniu widocznego podziału na

28 Dwuznaczność rozumienia praw człowieka obnaża doskonale Agamben w cytowanym tu już artykule pt. „My uchodźcy”, w którym tłumaczy, iż prawa człowieka nierozerwalnie powiązane są z rozumieniem człowieka nierozłącznie jako obywatela, co ujawnia się już choćby w samym tytule Deklaracji Praw Człowieka i Obywatela.

29 J.C. Pinos, dz. cyt., s. 22. Por. także statystyki publikowane na stronach: <www. iom.int>; <www.frontex.europa.eu>, dostęp: 15.11.2015. 
„nas” i „obcych”. Fizyczny obiekt - mur - kumuluje na sobie ludzi, którzy w innym wypadku byliby rozproszeni i mniej uchwytni. W ten sposób imigranci tworzą anonimową grupę, którą łatwo jest zdefiniować w upraszczających ją kategoriach. Nie widzimy zatem jednostek - konkretnych ludzi, i ich osobnych tożsamości. Kluczowe okazuje się więc to, że mur stanowi fizyczną, wizualną reprezentację konfliktu i podziałów charakteryzujących Europę i świat po drugiej stronie omawianej granicy i w konsekwencji sprzyja legitymizacji szeregu praktycznych działań dokonywanych w politycznym wymiarze.

\section{Od wykluczenia do autoseparacji}

Wraz z wejściem Hiszpanii do Unii Europejskiej, a potem do państw strefy Schengen, Ceuta i Melilla „zeuropeizowały” się w najwyższym stopniu $^{30}$. Stały się przede wszystkim zewnętrznymi miastami granicznymi Unii Europejskiej. Ich rola i pozycja jako takich stała się dominująca wobec faktu graniczenia między dwoma państwami. W związku z tym na ich granicy zaczęły koncentrować się działania dokonywane przez Unię Europejską zmierzające do zabezpieczenia dostępu nie tylko do Hiszpanii, ale do Europy w ogóle.

W 2005 roku została powołana do życia Europejska Agencja Zarządzania Współpracą Operacyjną na Granicach Zewnętrznych Państw Członkowskich Unii Europejskiej, z siedzibą w Warszawie, w skrócie Frontex $^{31}$. Swoje zainteresowanie skierowała ona oczywiście także na omawiane tu pogranicze. Jednym z zadań, do których Frontex został powołany, jest wspomaganie państw członkowskich UE przy wydalaniu nielegalnych imigrantów. Frontex dysponuje dużymi środkami finansowymi oraz rozbudowaną infrastrukturą technologiczną umożliwiającą wykrywanie potencjalnego zagrożenia dla Europy. Budżet na 2011 rok opiewał na $86 \mathrm{mln}$ euro, natomiast budżet na rok 2015 to już $142,6 \mathrm{mln}$ euro $^{32}$. Wzrost budżetu Frontexu jest zresztą ciągle zapowiadany w związku ze zwiększającym się naporem imigrantów na Europę. Technologiczne wzmocnienie murów, które po 2005 roku dokonało się w Melilli i Ceucie, finansowane było częściowo zatem nie tylko bezpośrednio przez Unię Europejską (jak to miało miejsce już wcześniej), ale także wsparte zostało przez specjalnie do tego powołaną instytucję. Frontex jest

\footnotetext{
30 S. Saddiki, dz. cyt., s. 9.

$31<$ http://frontex.europa.eu>, dostęp: 15.11.2015.

32 Tamże.
} 
także agencją mającą legitymację do współpracy z służbami granicznymi państw nie wchodzących w skład Unii Europejskiej, w szczególności „identyfikowanych jako źródło lub ścieżki tranzytowe nieuregulowanych migracji”33.

Powstanie takiej agencji, specjalnej jednostki nakierowanej na problem obrony zewnętrznych granic Europy stanowi wydarzenie bez precedensu w politycznej historii UE i rezonuje także w jej sferze symbolicznej. Dowodzi bowiem namacalnie, iż odrębność Europy stanowi wartość samą w sobie, której w zglobalizowanym świecie chce ona strzec w sposób wyjątkowy. Z jednej strony definiuje się i wyklucza tych, którzy są „obcy” wraz z całym symbolicznym bagażem odmienności w sferze idei, wartości czy religii, które owi „oni” reprezentują, z drugiej jednak strony Europa sama do pewnego stopnia próbuje separować się, ignorując poniekąd realia zglobalizowanego świata i odcinać się od niego na zasadzie „zamkniętej społeczności” (,gated community”), starając się dopuścić do siebie tylko tych, którym na to pozwoli. W tym świetle istniejące w Ceucie i Melilli mury bynajmniej nie świadczą o końcu ery przestrzeni, o której pisał Bauman, ale stają się raczej znakiem nowego paradygmatu przestrzennego. W jego ramach powstające gdzieniegdzie coraz pilniej strzeżone fizyczne granice, zaczynają pełnić istotną funkcję, która pozwala na wykluczenie lub określenie przynależności ${ }^{34}$. Nie zawsze przebiegają one tam, gdzie istnieją faktyczne granice państw. Jednak tam, gdzie w takiej formie powstają, na nowo rysują polityczną mapę świata, dzieląc go na obszary mniej i bardziej uprzywilejowane.

$\mathrm{Z}$ drugiej strony wieże strażnicze i drut kolczasty oddzielający w Ceucie i Melilli Europę od reszty świata odczytywać można także w perspektywie specyficznego więzienia, w którym Europa sama się zamyka. Im większy poziom separacji, czyli im wyższy mur, im ściślejsza ochrona, tym bardziej wzrasta poczucie zagrożenia wobec tego, co na zewnątrz. Tym bardziej odlegli od nas i obcy nam stają się ci „obcy” po drugiej stronie muru. Stają się też coraz bardziej anonimowi. W praktyce mogą być to „zwykli” ludzie, tacy sami jak ci, którzy żyją po drugiej stronie muru. Zazwyczaj ich motywacje przedostania się do Europy są pozytywne, a ich intencje pokojowe. Istniejacy mur zmienia jednak wyobrażenie o nich i umieszcza ich w rolach coraz mniej przyjaznych i coraz trudniejszych do oswojenia. Jak zauważył Xavier Ribas, zaczynamy żyć w równoległych, wielkich kapsułkowych światach - przestrzeniach, ogrodzonych technolo-

$33<$ http://frontex.europa.eu/about-frontex/mission-and-tasks>, dostęp: 15.11.2015.

$34 \mathrm{O}$ problematyce granicy szeroko pisze: S. Pickering, L. Weber, Borders, mobility and technologies of control, [w:] Borders, Mobility and Technologie of Control, red. S. Pickering, L. Weber, Dordrecht 2006, s. 2-19. 
gicznymi i fizycznymi murami ${ }^{35}$. Europa, budując takie bariery, nie tylko wyklucza innych, ale także sama się separuje, zwiększając napięcie między światem zewnętrznym a nią samą. Utrudnia zatem empatię i zrozumienie świata istniejącego poza nią, które konieczne jest dla osiągnięcia postaw koncyliacyjnych. Ich brak zaostrza natomiast występowanie niebezpiecznych postaw konfrontacyjnych, które niszcząc jedność Europy, mogą zagrozić jej bardziej, niż ludzie, od których odgradza się ona murem. W obliczu konfliktów wojennych rodzi ponadto pytania o kwestie etyczne, o granice owej empatii oraz o rzeczywiste znaczenie demokratycznych wartości poszanowania godności ludzkiego życia, na które Europa nie potrafi niestety odpowiedzieć w jednoznaczny i przekonujący sposób.

Kondycja Europy, która uwidacznia się w obliczu wzniesionych w Ceucie i Melilli murów, wpisuje Europę w globalny paradygmat podziału, który charakteryzuje współczesny świat. Powstające mury stanowią widoczny znak różnicy między wykluczającymi a wykluczonymi. Pozwalają pozytywnie zdefiniować tożsamość tych, którzy znajdują się "wewnątrz", wobec tych, którzy postrzegani są jako obcy, niebezpieczni i pozostają na zewnątrz „pożądanego” świata. Wreszcie, legitymizują konkretne działania w sferze politycznej, jako że stanowią praktyczny dowód na „wyobrażone” zagrożenie ze strony masy odpodmiotowionych jednostek zamkniętych w pojemnym pojęciu „imigranci”. Dają fikcyjne poczucie bezpieczeństwa płynące $\mathrm{z}$ przeświadczenia o życiu $\mathrm{w}$ dobrze chronionym społeczeństwie, choć poczucie coraz mocniej nadszarpywane kolejnymi zamachami na terenie Europy. Przenikalność granicy i przepływ ludzi jest jednak nieuniknionym faktem, który przenosi problemy zrodzone przez pogranicze do wewnątrz strzeżonego świata. Nie można jednak zapominać, iż ceną za wzniesione mury jest z jednej strony upokorzenie tych, dla których mur staje się znakiem fizycznej przemocy i podrzędności, z drugiej natomiast rosnące niezrozumienie świata znajdującego się po ich drugiej stronie. I choć wysokość tej ceny pozostaje ciągle nieznana, warto pamiętać o przesłaniu klasyka, który przypominał, że tam, gdzie powstają mury, rodzi się też potrzeba ich zburzenia, a wtedy może się okazać, że rzeczywiście „mury runą, runą, runą /i pogrzebią stary świat".

${ }^{35}$ X. Ribas, dz. cyt. 


\section{LITERATURA}

Agamben G., My, uchodźcy, przekł. K. Gawlicz, <http://www.egs.edu/faculty/giorgioagamben/articles/my-uchodzcy/>, dostęp: 15.11.2015.

Bauman Z., Społeczeństwo $w$ stanie oblężenia, Warszawa 2006.

Dziubiński A., Historia Maroka, Wrocław 1983.

Kennedy J.F., Przemówienie na Rudolph Wilde Platz, Berlin, 26.06.1963, <http:// www.jfklibrary.org>, dostęp: 15.11.2015.

Latour B., Splatajac na nowo to, co społeczne. Wprowadzenie do teorii aktora-sieci, Kraków 2010.

Mutlu C.E., Leite Ch.C., Dark side of the rock: borders, exceptionalism, and the precarious case of Ceuta and Melilla, „Eurasia Border Review” 2012, nr 3.

Ortuño J.M., Migration, Asylum and Security: The Case of Ceuta and Melilla, Malta, 2005, <http://www.libertysecurity.org/IMG/pdf/CHALLENGE-The_Case_of_Ceu ta_and_Melilla.pdf>, dostęp: 15.11.2015.

Pickering S., Weber L., Borders, Mobility and Technologies and Control, w: Borders, Mobility and tchnologie odf Control, red. S. Pickering, L. Weber, Dordrecht 2006.

Pinos C., Building Fortress Europe? Schengen and the Case of Ceuta and Melilla, Center for International Border Reseach, Belfast 2009, s. 18-22, <http://www. qub.ac.uk/research-centres/CentreforInternationalBordersResearch/Publications /WorkingPapers/CIBRWorkingPapers/Filetoupload,174398,en.pdf>, dostęp: 15.11. 2015.

Ribas X. The Border Fences of Ceuta and Melilla. A landscape for the Future?, <http:// www.xavierribas.com/Contents/Ceuta/Ceuta.html>, dostęp: 15.11.2015.

Saddiki S., Ceuta and Melilla Fences: a EU Multidimensional Border?, Montreal 2010, <http://www.cpsa-acsp.ca/papers-2010/Saddiki.pdf>, dostęp: 15.11.2015.

Welzer H., Wojny klimatyczne: za co będziemy zabijać w XXI wieku?, Warszawa 2010. $<\mathrm{http} / / / \mathrm{www}$.iom.int>

$<$ http://frontex.europa.eu> 